\title{
ENERGY STORAGE SYSTEM WITH THE USE OF SUPERCAPACITORS
}

\section{Wiesław Tarczyński, Ryszard Kopka}

Opole University of Technology, Faculty of Electrical Engineering, Automatic Control and Informatics, Prószkowska 76 Str., 45-758 Opole, Poland; e-mail: \{w.tarczynski; r.kopka\}@po.opole.pl

\begin{abstract}
The article presents an analysis of performance of an energy storage element used in uninterruptible power supply systems built with the use of supercapacitors. It describes the operation of the voltage balancing system during charging and discharging of the capacitors. Attention has been drawn to the energy conditions of the system's operation and solutions that provide enhanced energy efficiency have been described.
\end{abstract}

Key words:

UPS, energy storage, supercapacitor, voltage balancing system.

Research article

(C) 2018 Wiesław Tarczyński, Ryszard Kopka This is an open access article licensed under the Creative Commons Attribution-NonCommercial-NoDerivatives 4.0 license (http://creativecommons.org/licenses/by-nc-nd/4.0/) 


\section{INTRODUCTION}

Along with the development of technology, there is a growing demand for electrical energy. At the same time, more and more attention is drawn to its quality. One of the principal elements, which determine the quality of electrical energy is the continuity of its supply, especially during interruptions in the operation of the main power system. The increasing demands concerning the quality of the supplied electricity are mainly due to the application of energy load points in a broader range, which proper operation is strongly dependent on the quality of the supplied electrical energy. Such devices include, for example, medical equipment, communication systems, ICT systems, electrical and electronic devices used in manufacturing, emergency (evacuation) lighting systems, power systems in aircraft, ships, etc.

To ensure continuity of supply it is necessary to store electrical energy during normal operation of the main power system and making use of it during its failure. The method of energy storage depends primarily on the amount of energy that we want to store and on the conditions in which it will be used.

Electrical energy can be stored in various ways, e.g. in chemical storage cells, fuel cell systems, flywheels, compressed gas, and huge capacities supercapacitor blocks [6]. Each method has its advantages and disadvantages, manifested in the place of their use.

In most cases, before the stored electrical energy is used it must be processed to a state suitable for the conditions of its use. Most methods of energy storage refer to the systems in which it is available in the form of DC voltage. To store energy, an energy storage device is need, which can be used in uninterruptible or backup supply systems.

Uninterruptible power supply systems, the so-called UPS systems are nowadays the principal systems which ensure supplying selected load points in a way that assures a continuous electrical energy supply especially in conditions when the work conditions of power networks or another principal supply source are interrupted.

The principal function of uninterruptible (emergency) power systems is to ensure adequate and rather constant voltage level at the time of disappearance, collapse, break, fluctuation, or other interference occurring in the primary source [7].

Uninterruptible power systems can also perform the function of conditioning energy derived from the so-called unsteady sources e.g. windmills, power generators, solar cells, etc.

The basic parameters of uninterruptible (emergency) supply apparatuses are: power, nominal voltage, amount of stored energy, the switching time from the primary 
power source to the time of power supply from the backup source, maximum possible duration of supply under specified load conditions, energy efficiency, installation cost, and operating cost $[2,4,8]$.

An almost perfect uninterruptible power supply source is such that has a sufficiently large energy source, high power, very short switching time, a very long time of energy supply, low cost of production and operation. The actually used sources of power supply have properties that are based on a compromise between different expectations. The selection of the backup power supply apparatus depends on its specific application. For example, systems used for supplying computer installations must be characterised by zero switching time and the minimum time of energy supply should be such as to allow this equipment to safely store the currently processed data. In turn, systems for suppling communication or navigation devices, must also be characterised by a zero switching time, and further ensure the supply of energy during the time required to start up a source that provides power until the time when the main power source is brought back to full operation e.g., start-up of an electrical current generator or switching to another power source [8].

UPSs are mainly used in those power systems which require very short or zero switching time. This is especially important for supplying computer, communication, and navigation systems, medical equipment, as well as ships and aircraft control systems.

UPSs are built in a wide range of output power and maximum operation time. The energy efficiency of UPSs is relatively high and can be higher than $90 \%$. It depends on the type of system, properties of the applied electronic systems (inverters, converters), as well as properties of the energy storage devices.

The UPS is composed of energy storage element, charging system, conditioning system with output for connection of the load. Electricity receivers may be DC or AC. Direct current receivers are used mainly in: telecommunication systems, evacuation lighting power supply, as auxiliary power supply in power facilities, power supply in cars, sailing ships, aircraft, etc. However, in most cases electrical energy receivers are adapted to being supplied by alternating current.

The task of the conditioning system for receivers of direct current is to ensure voltage on an appropriate level and with appropriate stability. In the case of $\mathrm{AC}$ receivers the conditioning system must be replaced by a $\mathrm{DC}$ to $\mathrm{AC}$ converter and at the same time it must ensure an appropriate quality of this voltage through maintaining of an appropriate frequency, harmonic distortion, constant amplitude at a specific load current. 


\section{ENERGY STORAGE UNITS IN UPS SYSTEMS}

If energy receiver are DC systems and the energy storage unit is a pack of chemical batteries as shown in figure 1, then in most cases, we can skip the use of a conditioning system and powered the receivers directly from the storage unit. This is because the changes of voltage on the batteries terminals during its discharge are relatively small.

Lead-acid in different variations, alkaline, and recently introduced lithium-ion batteries are used as energy storage units. The main disadvantages of batteries are a relatively short lifetime (up to a few years), high risk to the surroundings and the environment, weight, long charging time, critical charging conditions, a large effect of temperature on capacity and high sensitivity to transportation conditions. In turn, the benefits of batteries are: high energy density per weight unit, relatively low cost, ability to series connection in order to obtain higher voltage or small changes in voltage between full load and allowable discharge.

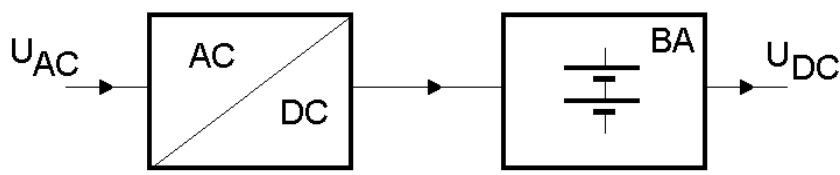

Fig. 1. UPS system with constant output voltage and a battery pack as an energy storage: $\mathrm{AC} / \mathrm{DC}$ - charging system, BA - battery pack, $U_{\mathrm{AC}}$ - supply voltage, $U_{\mathrm{DC}}-$ constant output voltage [own study]

In a UPS with a batteries pack, the storage units are charged from an AC/DC charge system, which can be, for example, a current regulator with a voltage limit. The charge system is supplied with alternating voltage $U_{\mathrm{Ac}}$. In modern systems, the charging process is controlled by microprocessor systems. The objective of this system is the selection of the charging current and voltage to ensure optimal operating conditions, especially those that provide long storage unit life.

Some of the shortcomings of storage units and particularly the required strict charging conditions have caused that more and more often storage units are replaced by supercapacitors.

Supercapacitors are characterised first of all by: very large capacity, possibility of quick charging and discharging, high efficiency cycle of charge and discharge, a large number of charge and discharge cycles, minimum threat to the environment, small impact of temperature on capacity, ability to operate in any position, high resistance to current overload, ability to fully discharge without a negative impact on the properties. In turn, the disadvantages are: high cost, low energy density, low value 
of the maximum permissible voltage of one capacitor, need to use systems for equalising the voltage on each capacitor in a series connection, as well as a large dependence of the voltage at the capacitor terminals on the degree of charge-discharge.

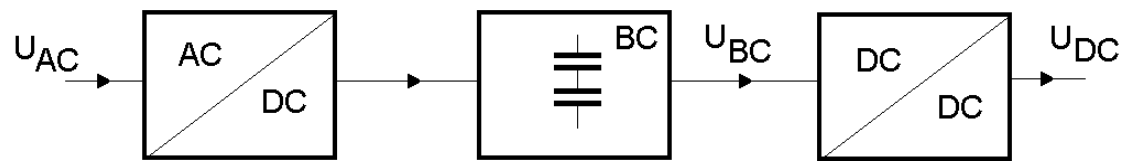

Fig. 2. Diagram of the UPS system with constant output voltage and a supercapacitor pack as an energy storage: $\mathrm{BC}-$ a pack of supercapacitors, $\mathrm{DC} / \mathrm{DC}$ - constant current converter, the remaining designations as in fig. 1 [own study]

The use of supercapacitors as an energy storage in UPSs requires connecting supercapacitors in series and parallel systems. Parallel connection of supercapacitors is used to obtain the desired capacity while series connection is used to obtain an appropriate value of the maximum voltage between the pack terminals. The need for series connection of the supercapacitors results from low maximum threshold voltage $U_{\text {th }}$ of a single capacitor, which does not exceed $2.7 \mathrm{~V}$. The number of capacitors connected in a series results from the minimum voltage of the storage unit at which it is cost-effective to transform it to direct or alternating voltage with the use of electronic systems. In practice, the value of this voltage falls in the range from 40 to $60 \mathrm{~V}$, while the lower value is used in systems that use transistors, characterised by a voltage drop at conduction not exceeding 1 to $1.5 \mathrm{~V}$ (e.g. MOSFET transistors), and a higher voltage when using transistors with a drop of up to $2.5 \mathrm{~V}$ (e.g. bipolar transistors, IGBT).

A small voltage drop on the attached transistor in relation to the supply voltage ensures a greater use of the source voltage (energy storage unit), which in turn has a positive effect on the efficiency of the transforming process. A diagram of the UPS system with the use of an energy storage built using a pack of supercapacitors (BC) is shown in figure 2 . An alternating voltage $U_{\mathrm{AC}}$ is supplied to the AC/DC charging system input, which provides energy for charging the supercapacitors packs' - BC. Since the voltage at the terminals of the supercapacitor packs $U_{\mathrm{BC}}$ depends on the degree of the supercapacitors' charge, therefore, to maintain the output DC voltage $U_{\mathrm{DC}}$ with a value independent of the voltage on the supercapacitors, it is necessary to use a DC/DC converting system. The converting system may be for example a pulse voltage stabiliser. Whereas, in the case when an additional galvanic isolation of the output voltage $U_{\mathrm{DC}}$ from the supercapacitor packs' voltage $U_{\mathrm{BC}}$ is required, then a DC converter (of the DC-DC type) must be used, in which isolation is achieved through the use of a high frequency transformer. 


\section{ENERGY STORAGE SYSTEMS WITH THE USE OF SUPERCAPACITORS}

A diagram of an energy storage system with the use of supercapacitors is shown in figure 3. The number of $m \times n$ supercapacitors applied for the construction of an energy storage unit is derived from the required capacity while the number of cells $m$, connected in series comes from the required voltage value at the maximum charge.

The allowable, relatively low - voltage on one capacitor, causes that in the case of serial connection of the supercapacitors it is necessary to use systems that regulate the voltage on each capacitor (voltage balancing system B1 - Bm), so that in all operating conditions the value of voltage $U_{\text {th }}=2.7 \mathrm{~V}$ is not exceeded and to prevent a change of the polarity of the voltage on the capacitor at discharge. Exceeding the value of the voltage $U_{\text {th }}$ starts the chemical processes inside the capacitor, which can lead to irreversible damage. In turn, the change of polarity of the capacitor at discharge leads to a decrease in the amount of energy that can be recovered from the storage unit.

Using voltage balancing systems on the capacitor causes, however, limiting of the values of the charging and discharging current. The charging process of supercapacitors forming energy storage unit, can be performed in a system in which the capacitors are connected in a series as shown in Fig. 3 or in a system, in which - for the charging time - the connection system is changed to parallel. However, parallel connection for charging time, preclude the possibility of simultaneous getting of energy during charging and it requires the use of a charging system with high current efficiency. That is the main reasons that this method of charging is used very rarely and then only in special cases.

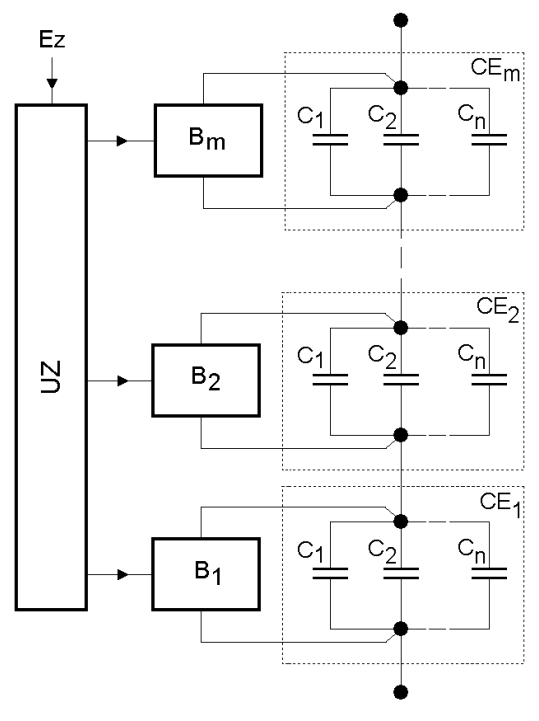

142
Fig. 3. Energy storage system with the use of supercapacitors: $\mathrm{C}_{1}-\mathrm{C}_{n}-$ supercapacitors, $\mathrm{CE}_{1}-\mathrm{CE}_{\mathrm{m}}$ - storage packs, EZ - power supply, $\mathrm{UZ}$ - supply system of the voltage balancing units, $B_{1}-B_{m}-$ voltage balancing systems for each pack of supercapacitors [own study]

Scientific Journal of PNA — Zeszyty Naukowe AMW 
The value of capacitance of supercapacitors even of the same type may differ between each other in a range of $-20 \%$ to $+50 \%$. The diversity of the capacity causes some difficulties in their operation. This is particularly manifested while charging and discharging in energy storages systems in which the capacitors are connected in a stack. Different capacities of the capacitors cause that the distribution of voltage on the capacitors during charging/discharging will not be identical.

\section{CHARGING SUPERCAPACITORS IN A SERIAL/PARALLEL SYSTEM}

In the case of a serial/parallel connection of the capacitors, each unit consisting of capacitors connected in parallel must have their individual voltage balancing system $B_{i}$. While charging, the voltage balancing system cannot allow for exceeding of the threshold voltage i.e. $U_{\mathrm{th}}=2.7 \mathrm{~V}$. Until the voltage exceeds the allowable value $U_{\text {th }}$, the whole charging current $I$ flows through the $m$-pack of supercapacitors ( $\mathrm{CE}_{\mathrm{m}}$ ). After charging the supercapacitors to a threshold value $U_{\text {th }}$, the voltage balancing system $B_{i}$ has to switch to the voltage stabilisation mode and maintain the voltage on the capacitor at a level of $U_{\text {th }}$ despite the current $I$. Such operation of the balancing system causes that the supercapacitor current drops down to zero (more precisely to the supercapacitor leakage current), and the whole charging current $I$ will then flow through the voltage balancing system, causing power losses in it.

If the actuator which regulates the flow of the current through the balancing system is a transistor then the power losses $P_{\text {loss }}$ in one balancing system will be equal to

$$
P_{\text {loss }}=U_{\mathrm{th}} I,
$$

where $I$ is the charging current, here the current flowing through the voltage balancing system.

This power will the transistor's temperature $T_{\mathrm{j}}$ to rise and its maximal value will depend on the cooling method. If it is assumed that the temperature control of the transistors will be implemented only through a system consisting of a heat sink (metal) with a given mass $m$ and the specific proper heat $c$ and it is assumed that the thermal resistance between transistor and heat sink may be skipped and the current $I$ will flow over time $t$, then the temperature increase $\Delta T$ inside the transistor can be determined as

$$
\Delta T=\frac{U_{\mathrm{th}} I t}{m c},
$$


where $m$ is heat sink mass, $c$ the specific proper heat, $U_{\text {th }}$ the maximum voltage (threshold) of the capacitor equal to $2.7 \mathrm{~V}$ and $t$ the time of charging current $I$ flow through the transistor.

Considering a maximum ambient temperature $T_{\mathrm{a} \text { max }}$, which is in this case the initial temperature of the transistor, the temperature of the semiconductor in the transistor will reach the value

$$
T_{\mathrm{j}}=T_{\mathrm{a} \max }+\Delta T
$$

and should be lower than the maximum allowable temperature $T_{\mathrm{j} \max }$ for a given transistor type defined by the manufacturer, so it should be

$$
T_{\mathrm{j}}<T_{\mathrm{j} \max } .
$$

It results from (2) that limiting temperature growth may be obtained by reducing the time $t$ of current flow through the transistor or by increasing the mass $m$ and specific proper heat $c$ of the heat storage.

If an energy storage unit needs to obtain a load $Q=I t$, then reducing the charging time $t$ entails the need to increase the charging current $I$. In turn increasing the charging current $I$ requires increasing current efficiency of the charging system and using in the voltage balancing systems transistors with a greater current resistance, which is not always economically profitable.

The method of limiting the temperature of the transistors due to only using the heat capacity of the cooling system entails, however, the risk of overheating in the case, if there is subsequent charging before the heat tank cools down completely. Therefore, this method of reducing the temperature of the transistors requires the use of a transistor temperature control system in the current balancing system. This system should control the charging process through ongoing control of the charging current $I$ and in the case of exceeding the temperature $T_{\mathrm{j} \text { max }}$ the charging process must be interrupted.

A $\mathrm{CE}_{\min }$ cell of supercapacitors, which total capacitance is the lowest of all cells will reach the threshold voltage $U_{\mathrm{th}}=2.7 \mathrm{~V}$ the fastest (in time $t_{\mathrm{min}}$ ). During this time, none of the cells will achieve the voltage threshold value and therefore all energy supplied from the charging system will be transferred to others supercapacitor's cells. The cell $C E_{\max }$, with the greatest capacity will be charged to the value $U_{\text {th }}$ for the longest time (in time $t_{\mathrm{c}}$ ).

If in order to charge stack of supercapacitors a charging system with voltage limit is used, when the voltage of storage unit reaches the value equal to $U_{\mathrm{BC}}=m U_{\mathrm{th}}$, then the system will automatically switch to voltage stabilisation mode and will maintain the value of this voltage at a constant level, then the charging current $I$ 
will drop to the value of zero (precisely to the supercapacitors leakage current). It follows further that this unit does not require an individual voltage balancing system during charging and therefore there will be no energy loss while it is being charged.

The total energy of losses $E_{\text {loss }}$ during charging with current $I$ to voltage $U_{\mathrm{BC}}=m U_{\mathrm{th}}$ in time $t_{\mathrm{c}}$, may be determined as

$$
E_{\mathrm{loss}}=U_{\mathrm{th}} I \sum_{i=1}^{m}\left(t_{c}-t_{i}\right),
$$

where $t_{\mathrm{i}}$ is the charging time of the $i$-cell of the supercapacitors bloc, $t_{\mathrm{c}}$ is the charging time of the cell with the greatest capacity and $m$ is the number of cells in the storage system.

Based on (5) it follows that in order to minimise losses during charging it is necessary to use the cells, which will be charged at the same time, which means that it is necessary to use cells with an as close as possible capacity.

The total energy $E_{\mathrm{c}}$ accumulated in all the capacitors after charging completion will be specified by

$$
E_{\mathrm{c}}=E_{\mathrm{d}}-E_{\text {loss }}
$$

where $E_{\mathrm{d}}$ is the energy supplied from the cells of the supercapacitors, $E_{\text {loss }}$ is the energy of the losses in the balancing systems.

The efficiency of the charging process will be determined as

$$
\eta=\frac{E_{\mathrm{d}}-E_{\mathrm{loss}}}{E_{\mathrm{d}}} .
$$

Improving the efficiency of the charging process can also be achieved by using voltage balancing systems with non-continuous action. However, such systems in their construction and operation are quite complex and require the use of control systems using the microprocessor technique. A complicated voltage balancing system also decreases reliability of the charging system $[1,3]$.

\section{DISCHARGING SUPERCAPACITORS IN A SERIAL/PARALLEL SYSTEM}

Each cell's capacity is also important when a block of supercapacitors is discharged. If the capacities of individual cells are equal or similar, then during the discharge time the voltage on each cell will drop to zero in the same way. When the capacity

1 (212) 2018 
of the individual cell is not equal, the discharge rate of individual cells will differ and the cell with the smallest capacity will be discharged to zero and then it will be recharged (it will change the polarity to the opposite) by a charge accumulated in capacitors of greater capacity.

The discharge process of the block of the capacitors will last until the voltage $U_{\mathrm{BC}}$ between the terminals of the storage device reaches zero. This value is the sum of the voltage $U_{i}$ between the terminals of individual cells, i.e.

$$
U_{\mathrm{BC}}=\sum_{i=1}^{m} U_{i}=0,
$$

where $U_{i}$ is the voltage between the terminals of the $i$-cell.

The voltage $U_{\mathrm{BC}}$ equals zero does not mean the zero voltage value $U_{i}$ for each individual cell. When the discharge process is completed, there will be cells, which the voltage will be positive and on some there will be negative voltage (opposite polarity relative to the primary one). The voltage value on each cell $\mathrm{CE}_{\mathrm{m}}$ and its polarity will depend on the cell total capacity $\mathrm{CE}_{j}$.

Non-zero voltage value between the cell terminals $U_{i}$ will cause that there will be accumulated energy in it, which cannot be recovered. The amount of available energy $E_{d}$ from all cells during discharge will be equal to

$$
E_{\mathrm{d}}=E_{\mathrm{B}}-\sum_{j=1}^{m} E_{r j},
$$

where $E_{r j}$ means the energy remaining in the $j$-cell, $E_{\mathrm{B}}$ is initial energy in the unit of supercapacitors. In the cells, in which the voltage value between the terminals will not equal zero, the energy that will remain is $E_{\mathrm{rj}}$. From this it follows that at the time of discharge it should not be allowed for the capacitors to change voltage polarity to an opposite one.

A simple and partially effective method that increases energy recovery is parallel connection to each cell a diode. If the cell is polarised in the opposite direction, the diode is polarised in the direction of conductivity and therefore the voltage value on the cell element is limited to the voltage of the diode. Since this voltage should be as small as possible, it is intentional to use Schottky diodes in which the conducting voltage is much less compared to classical silicon rectifier diodes.

The ideal option would be adding a system (contacts), which at the time of changing the polarity of voltage on the cell would cause the cell's short circuit and during charging the contacts would be opened. The only system (element), which 
can cause a complete short circuit of the cell is the relay contacts. However, this solution introduces an element into the system which is characterised by low reliability. In addition, the short-circuit would have to take place at the lowest possible voltage on the capacitor. This is necessary to minimise the flow of large short-circuit current at the moment of the connectors' short circuit.

MOSFET low-voltage transistors may be used instead of the relay connectors, but with a very low drain-source resistance (below $1 \mathrm{~m} \Omega$ ) and a relatively high on-state current (up to several hundred amps).

\section{COMPUTER SIMULATION OF THE OPERATION OF THE ENERGY STORAGE SYSTEM WITH SUPERCAPACITORS}

Figure 4 shows a diagram of a system with the use of which a simulation of the process of charging and discharging of an energy storage unit using supercapacitors was performed. The simulation was performed for an energy storage unit consisting of three cells of supercapacitors $\mathrm{CE}_{1}, \mathrm{CE}_{2}, \mathrm{CE}_{3}$ with a capacity of $5 \mathrm{~F}, 8 \mathrm{~F}$, $10 \mathrm{~F}$, respectively. Zener diodes were used as voltage balancing systems $\mathrm{D}_{1}-\mathrm{D}_{3}$ with threshold voltage $U_{\mathrm{Z}}=2.7 \mathrm{~V}$. The storage system was charged from a DC current source $I_{\mathrm{DC}}$ with current $I$ of $12 \mathrm{~A}$. The current $I_{\mathrm{B}}$ of each diode, the $I_{\mathrm{C}}$ current flowing through the each capacitors $C$ and the voltage $U_{C}$ on each capacitor during charge and discharge were observed.

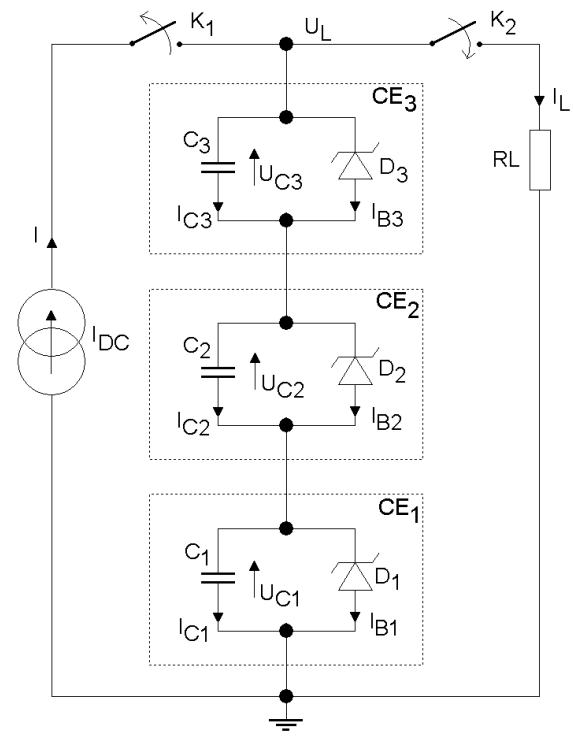

Fig. 4. The diagram of the energy storage system used for the computer simulation: I - charging current; $I_{\mathrm{DC}}$ - current source; $\mathrm{K}_{1}, \mathrm{~K}_{2}$ - keys; $\mathrm{C}_{1}-\mathrm{C}_{3}$ - capacitors; $\mathrm{D}_{1}-\mathrm{D}_{3}-$ Zener diodes (voltage balancing system); $U_{\mathrm{L}}$ - energy storage voltage; $\mathrm{R}_{\mathrm{L}}$ - discharging resistor; $I_{\mathrm{L}}$ - discharge current; $\mathrm{I}_{\mathrm{C} 1}-\mathrm{I}_{\mathrm{C} 3}$ - capacitor currents; $\mathrm{I}_{\mathrm{B} 1}-\mathrm{I}_{\mathrm{B} 3}-$ voltage balancing system currents; $\mathrm{U}_{\mathrm{C} 1}-\mathrm{U}_{\mathrm{C} 3}-$ voltage on the capacitors [own study] 


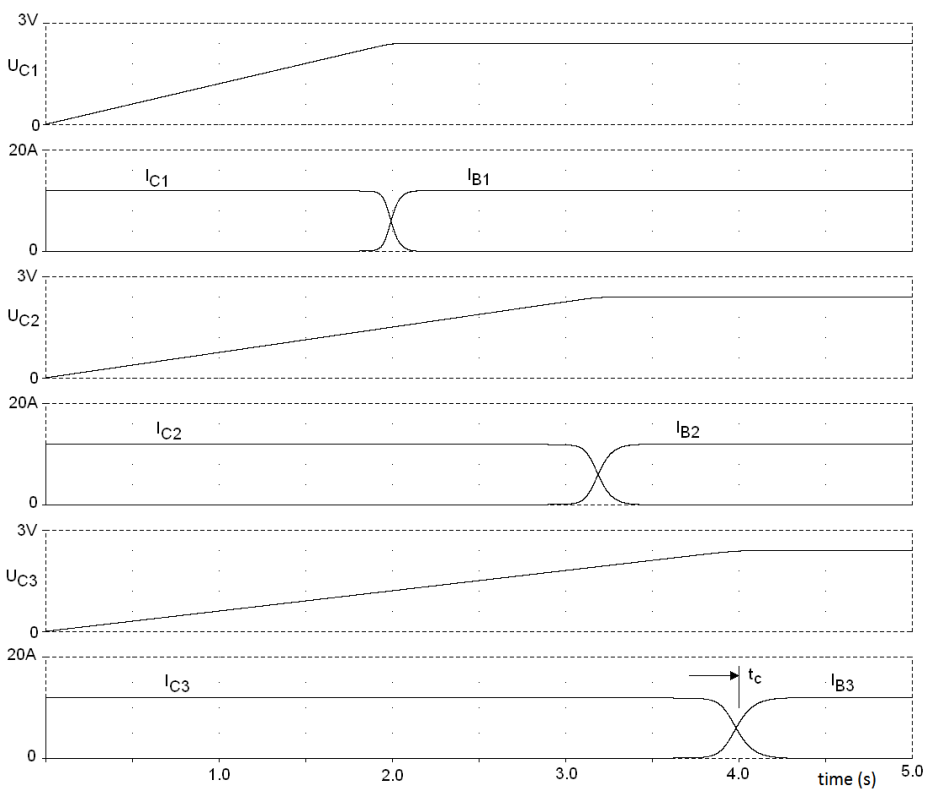

Fig. 5. The voltages and currents of the supercapacitors of the energy storage system during charging time: $\mathrm{I}_{\mathrm{B} 1}$, $\mathrm{I}_{\mathrm{B} 2}$, IB3 - the current of voltage balancing unit B1, B2, B3, respectively;

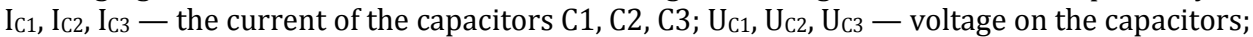
$t_{c}$ - charging time of the cell with the largest capacity [own study]
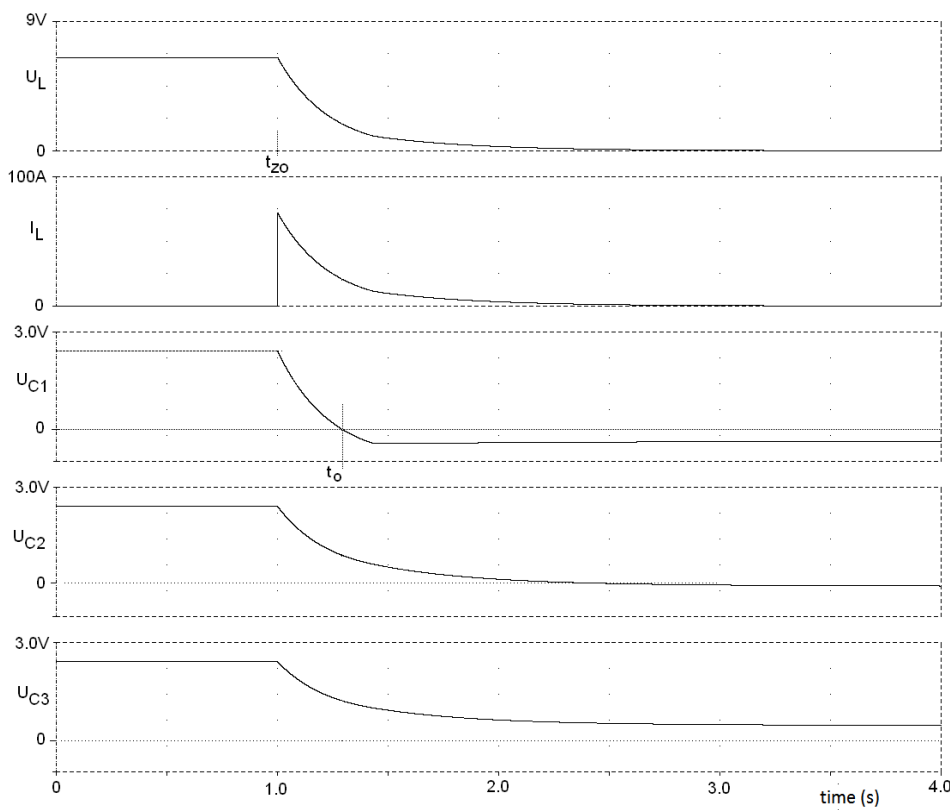

Fig. 6. The voltages and currents of the supercapacitors terminals during their charging: $I_{\mathrm{L}}, U_{\mathrm{L}}-$ current and voltage on the discharging resistor $R_{L}$ respectively; $t_{0}$ - time in which the voltage on the capacitor $\mathrm{C}_{1}$ has reached the value of zero; other designations as in fig. 5 [own study] 


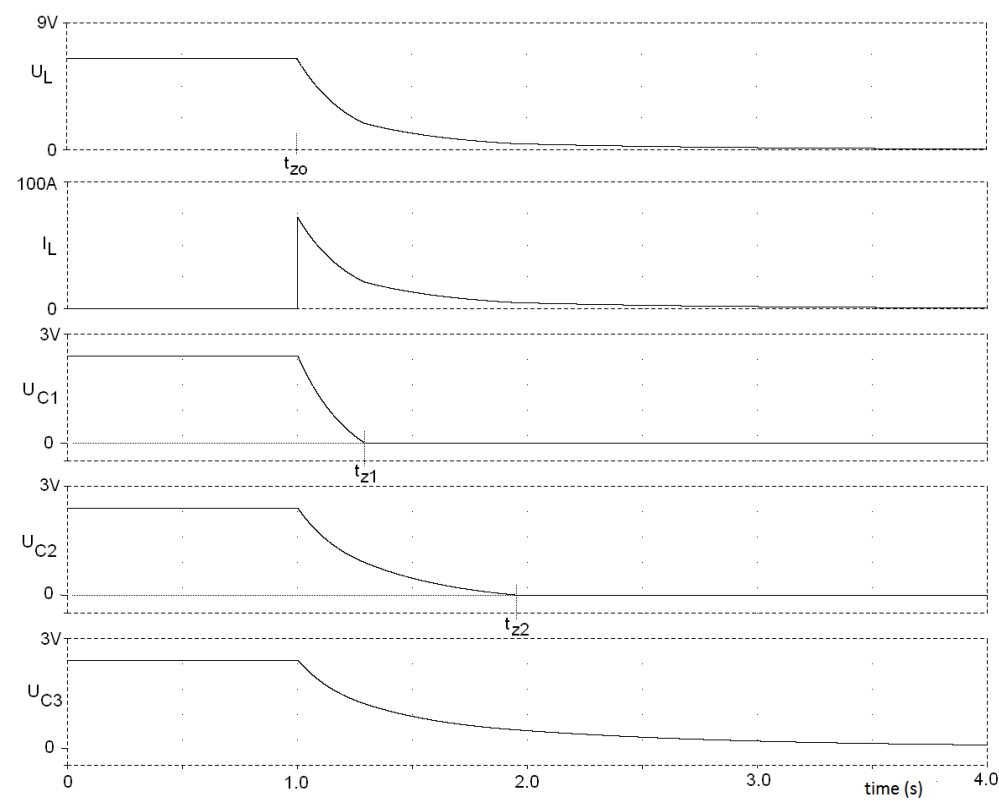

Fig. 7. The voltage and currents of the energy storage capacitors during discharge with a short circuit system: $I_{\mathrm{L}}, U_{\mathrm{L}}$ - current and voltage on the discharging resistor $\mathrm{R}_{\mathrm{L}}$ respectively;

$t_{\mathrm{z} 0}$ - discharge start time; $\mathrm{t}_{\mathrm{z} 1}, \mathrm{t}_{\mathrm{z} 2}$ - time in which the voltage on the capacitor $\mathrm{C}_{1}, \mathrm{C}_{2}$ has reached the value of zero; other designations as in fig. 5 [own study]

During charging the key $\mathrm{K}_{1}$ is closed for the time until voltage on all capacitors reaches the $2.7 \mathrm{~V}$. Next, the key $\mathrm{K}_{1}$ is opened and the key $\mathrm{K}_{2}$ is closed, beginning of the process of discharging the supercapacitors by the resistor $\mathrm{R}_{\mathrm{L}}$. The changes of voltage and currents during charging procedure are shown in figure 5 . It can be seen that the supercapacitor C1 with the lowest capacity is charged the fastest. The charging current of this capacitor drops down to zero while the current flowing through the voltage balancing system, i.e. through the Zener diode, goes up. Next, the voltage of $2.7 \mathrm{~V}$ is reached by the subsequent capacitors and the last one to reach the voltage of $2.7 \mathrm{~V}$ is the capacitor with the largest capacity.

Figure 6 shows the voltage and current changes during discharge by the resistor RL with a resistance value of $0.1 \Omega$. The capacitor $\mathrm{C} 1$, which has the smallest capacity discharges to zero the fastest and then it recharges in the direction of the opposite polarity to the Zener diode's voltage value polarized in the direction of conduction. The process of discharging ends when the voltage $U_{\mathrm{L}}$ reaches zero. Despite the fact that the value of the voltage $U_{\mathrm{L}}$ is equal to zero further discharge of the capacitors will not be possible and it will not be possible to recover the energy stored in them.

Figure 7 shows the voltage changes, in which during discharging of the supercapacitors those supercapacitors terminals are closed, which voltage reaches 
the value of zero. Closing these supercapacitors prevents their overcharging, which prevents the accumulation of energy which later cannot be recovered. As it can be seen is possible to fully discharge every supercapacitor.

\section{CONCLUSIONS}

Based on the analysis of the proposed voltage balancing system's operation dedicated to use in the energy storage constructed using a serial connection of supercapacitors it follows that the properties of such system decide about its operational properties. During charging of the supercapacitors, the current limit of the voltage balancing system will determine the maximum charge current, and therefore, the minimal charging time will be defined. In order to limit the losses during charging, the charge current flow must be limited to the time in which all the supercapacitors reach the charged state. In turn, during the discharge of the supercapacitors, it will be favourable to closed individual cells at the moment when the voltage between their terminals reaches zero. Closing the terminals cell prevents the cell from overcharging in the opposite direction and thus it will enable increasing energy which can be recovered. It is important to construct energy storage unit consisting of supercapacitor cells of the closest as possible capacity.

The flow of the charging current through the voltage balancing system will cause power losses that will result in temperature rise and therefore, they should be equipped with temperature control systems and cooling systems of appropriate efficiency.

\section{REFERENCES}

[1] Chang Ch., Yang J., Li Y., Zhu Z., Research of Supercapacitor Voltage Equalization Strategy on Rubber-Tyred Gantry Crane Energy Saving System, 'Energy and Power Engineering', 2010, Vol. 2, No. 1, pp. 25-30.

[2] Fiorina J. N., Uninterruptible static power supplies and the protection of persons, Publ. Schneider Electric, 'Cahier Technique' collection, 2004, No. 129.

[3] Grzesiak W., Maj T., Radziemska E., Supercapacitors in Stand-Alonge PV Systems with Inastantaneous High Output Energy Pulses, XXXII International Conference of IMAPS-CPMP IEEE, Poland, Pułtusk 12-24.09.2008, pp. 107-116. 
[4] Kopka R., Tarczyński W., A fractional model of supercapacitors for use in energy storage systems of next generation shipboard electrical network, 'Journal of Marine Engineering \& Technology', in review.

[5] Loeffler Ch., Spears E., UPS Basics, pdf, Publ. Eaton Corporation, October 2011, [online], http://www.eaton.com/content/dam/eaton/markets/data-center/UPS-basics.pdf [access 08.09.2017].

[6] Rafik F., Gualous H., Gallay R., Crausaz A., Berthon A., Frequency, thermal and voltage supercapacitor characterization and modeling, 'Journal of Power Sources', 2007, Vol. 165, Issue 2, pp. 928-934.

[7] Rasmussen N., The Different Types of UPS Systems, pdf, Publ. Schneider Electric, White Paper 1, Rev. 7, 2011, [online], http://www.apc.com/salestools/SADE-5TNM3Y/SADE-5TNM3Y_R7_ EN.pdf?sdirect=true [access 08.09.2017].

[8] Suzuki T., Basic Knowledge Regarding Uninterruptible Power Supply (UPS), 'Technical Report', November 2015, No. 40, pp. 9-12.

\section{SYSTEMY GROMADZENIA ENERGII Z WYKORZYSTANIEM SUPERKONDENSATORÓW}

\section{STRESZCZENIE}

W artykule przedstawiono analizę własności elementów gromadzących energię przeznaczonych do zastosowań w systemach zasilania bezprzerwowego opartych na superkondensatorach. Pokazano efekty działań układów balanserów użytych podczas cykli ładowania i rozładowywania kondensatorów. Zwrócono uwagę na zmiany energii podczas takich procesów, tak aby osiągnąć maksymalną sprawność energetyczną.

\section{Słowa kluczowe:}

UPS, układy gromadzenia energii, superkondensator, układy balanserów napięcia.

Article history

Received: 19.09.2017

Reviewed: 13.02.2018

Revised: $\quad 15.03 .2018$

Accepted: 16.03.2018

1 (212) 2018 